Article

\title{
Clinical and Rehabilitative Predictors of Peak Oxygen Uptake Following Cardiac Transplantation
}

\author{
Katelyn E. Uithoven ${ }^{1, *}$, Joshua R. Smith ${ }^{2}{ }^{(0)}$, Jose R. Medina-Inojosa ${ }^{2}{ }^{(0)}$, Ray W. Squires ${ }^{2}$, \\ Erik H. Van Iterson ${ }^{3}\left(\mathbb{D}\right.$ and Thomas P. Olson ${ }^{2}$ \\ 1 School of Kinesiology, University of Minnesota, Minneapolis, MN 55455, USA \\ 2 Division of Preventive Cardiology, Department of Cardiovascular Medicine, Mayo Clinic, Rochester, \\ MN 55905, USA; smith.joshua1@mayo.edu (J.R.S.); medinainojosa.jose@mayo.edu (J.R.M.-I.); \\ squires.ray@mayo.edu (R.W.S.); olson.thomas2@mayo.edu (T.P.O.) \\ 3 Section of Preventive Cardiology and Rehabilitation, Cleveland Clinic, Cleveland, OH 44195, USA; \\ vanitee@ccf.org \\ * Correspondence: nyber131@umn.edu; Tel.: 763-486-2913
}

Received: 21 December 2018; Accepted: 16 January 2019; Published: 19 January 2019

\begin{abstract}
The measurement of peak oxygen uptake $\left(\mathrm{VO}_{2 \text { peak }}\right)$ is an important metric for evaluating cardiac transplantation (HTx) eligibility. However, it is unclear which factors (e.g., recipient demographics, clinical parameters, cardiac rehabilitation (CR) participation) influence $\mathrm{VO}_{2 \text { peak }}$ following HTx. Consecutive HTx patients with cardiopulmonary exercise testing (CPET) between 2007-2016 were included. $\mathrm{VO}_{2 \text { peak }}$ was measured from CPET standard protocol. Regression analyses determined predictors of the highest post-HTx $\mathrm{VO}_{2 \text { peak }}$ (i.e., quartile 4: $\mathrm{VO}_{2 \text { peak }}>20.1 \mathrm{~mL} / \mathrm{kg} / \mathrm{min}$ ). One hundred-forty HTx patients (women: $n=41(29 \%)$, age: $52 \pm 12$ years, body mass index (BMI): $27 \pm 5 \mathrm{~kg} / \mathrm{m}^{2}$ ) were included. History of diabetes (Odds Ratio (OR): $0.17,95 \%$ Confidence Interval (CI): 0.04-0.77, $p=0.021$ ), history of dyslipidemia (OR: 0.42, 95\% CI: 0.19-0.93, $p=0.032$ ), BMI (OR: 0.90, 95\% CI: 0.82-0.99, $p=0.022$ ), hemoglobin (OR: 1.29, 95\% CI: 1.04-1.61, $p=0.020$ ), white blood cell count (OR: 0.81, 95\% CI: 0.66-0.98, $p=0.033$ ), CR exercise sessions (OR: 1.10, 95\% CI: 1.04-1.15, $p<0.001$ ), and pre-HTx $\mathrm{VO}_{2 \text { peak }}$ (OR: 1.17, 95\% CI: 1.07-1.29, $p=0.001$ ) were significant predictors. Multivariate analysis showed CR exercise sessions (OR: 1.10, 95\% CI: 1.03-1.16, $p=0.002$ ), and pre-HTx $\mathrm{VO}_{2 \text { peak }}$ (OR: 1.16, 95\% CI: 1.04-1.30, $p=0.007$ ) were independently predictive of higher post-HTx $\mathrm{VO}_{2 \text { peak }}$. Pre-HTx $\mathrm{VO}_{2 \text { peak }}$ and $\mathrm{CR}$ exercise sessions are predictive of a greater $\mathrm{VO}_{2 \text { peak }}$ following HTx. These data highlight the importance of CR exercise session attendance and pre-HTx fitness in predicting $\mathrm{VO}_{2 \text { peak }}$ post-HTx.
\end{abstract}

Keywords: peak oxygen uptake; cardiopulmonary exercise testing; cardiac rehabilitation; exercise capacity; postoperative care

\section{Introduction}

Peak oxygen uptake $\left(\mathrm{VO}_{2 \text { peak }}\right)$ is an important metric for cardiac transplantation (HTx) eligibility. The measurement of exercise capacity using $\mathrm{VO}_{2 \text { peak }}$ obtained from cardiopulmonary exercise testing (CPET) is one criteria used for determination of transplant eligibility; with a value of $\leq 14 \mathrm{~mL} / \mathrm{kg} / \mathrm{min}$ considered transplant eligible [1-5]. The association between higher $\mathrm{VO}_{2 \text { peak }}$ and reduced hospitalizations and mortality risk has been shown in both the heart failure (HF) and HTx population, with even modest improvements in $\mathrm{VO}_{2 \text { peak }}$ associated with improved outcomes [6-9]. Because of this, investigating demographic and clinical factors that are predictive of post-HTx $\mathrm{VO}_{2 \text { peak }}$ has significant implications not only for functional capacity but also long-term survival. 
Previous studies have investigated demographic and clinical determinants of $\mathrm{VO}_{2 \text { peak }}$ in various populations [10-18]. For example, the predictive influence of age, sex, and body mass index (BMI) on $\mathrm{VO}_{2 \text { peak }}$ has been shown in healthy populations $[16,17]$. In HTx patients, these variables have also been shown to be prominent predictors of post-HTx $\mathrm{VO}_{2 \text { peak }}$ along with chronotropic reserve, donor age, and time from HTx $[11,13,14,18]$. However, a limitation of these previous studies is the small sample sizes used $(n=60-95)[11,13,14,18]$. In addition, recent work has indicated that participation in cardiac rehabilitation (CR) in HTx postoperative care has been shown to be related to improvements in $\mathrm{VO}_{2 \text { peak }}[15,19,20]$; however, it is unclear if $\mathrm{CR}$ participation is predictive of a greater $\mathrm{VO}_{2 \text { peak }}$ following HTx.

Therefore, the purpose of this study was to investigate whether pre-HTx clinical characteristics and/or postoperative $\mathrm{CR}$ exercise session attendance provide utility in predicting $\mathrm{VO}_{2 \text { peak }}$ following HTx. Based on previous studies on the relationship between $C R$ involvement and $\mathrm{VO}_{2 \text { peak }}[15,19,20]$, we hypothesize that $\mathrm{CR}$ will surpass other predictive factors of post-HTx $\mathrm{VO}_{2 \text { peak }}$ in $\mathrm{HTx}$ patients.

\section{Experimental Section}

\subsection{Participants and Study Design}

A retrospective, single-center study cohort design evaluated consecutive adult HTx patients who performed symptom-limited CPET prior to HTx (pre-HTx) and following HTx (post-HTx) between the years of 2007-2016. Demographic and clinical characteristics were obtained from an institutional database. Inclusion criteria included completion of pre-HTx CPET within 24 months prior to procedural date and post-HTX CPET within 1-year of HTx. Patients were excluded if they lacked CR exercise session data or had incomplete CPET data. Of the $204 \mathrm{HTx}$ patients, 140 were analyzed in this study (Figure 1). This study was approved by the Mayo Clinic Institutional Review Board (IRB \#15-007965) and followed research authorization protocol for the use of medical records as required by the state of Minnesota [21].

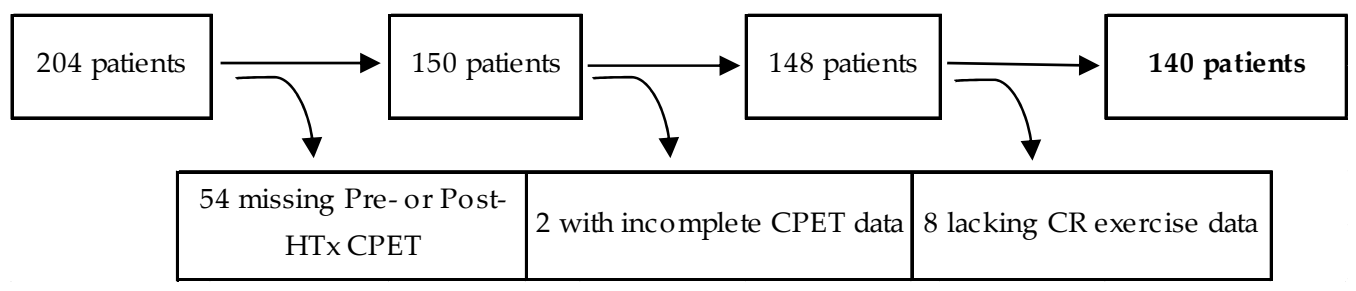

Figure 1. Flowchart for patient inclusion and exclusion. Of the initially identified 204 HTx patients, 54 patients lacked a pre-HTx or post-HTx CPET, 2 patients had incomplete CPET data, and 8 patients were lacking CR exercise session data, resulting in 140 patients for study analysis. HTx, cardiac transplantation; CPET, cardiopulmonary exercise testing.

\subsection{Clinical Characteristics}

Clinical baseline information from the time of HTx procedural date was obtained via medical record extraction. Demographic data along with previous disease history, previous left ventricular assist device (LVAD), current laboratory measurements (i.e., hemoglobin, hematocrit, white blood cell count, and creatinine), indication for HTx (i.e., restrictive cardiomyopathy, dilated cardiomyopathy, hypertrophic cardiomyopathy, ischemic cardiomyopathy, or other), and pre-HTx medication status for the following: angiotensin-converting enzyme (ACE) inhibitor, amiodarone, aspirin, beta blocker, calcium channel blocker, and diuretic were extracted from the procedural sedation assessment at the time of HTx. For the purpose of monitoring data correctness, two investigators independently reviewed a random sampling of medical record charts. 


\subsection{Cardiac Rehabilitation Participation}

Patients included in this study were referred for CR participation and attended at least one documented session following HTx. Medical records were examined to determine CR attendance specifically relating to postoperative HTx care versus CR for any cardiac-related event. As the initial visit for CR typically involves orientation procedures with little to no exercise involvement, this was not assessed in this study. Only those CR sessions with documented exercise participation were included for analysis. All exercise sessions were supervised throughout activity by clinical exercise physiologists with cardiologist oversight. During the course of CR participation patients performed 20-45 min of aerobic activity in a monitored setting, with the usual addition of strength training components for 10-15 min. In addition to $C R$ attendance patients were encouraged to partake in light to moderate physical activity for at least $30 \mathrm{~min}$ on all days of the week. Guidance regarding nutrition, medication management, stress management, and depressive symptom management were all components of the comprehensive approach of the CR program. Social support was also provided in this environment as patients all engaged in group education/learning activities throughout $C R$.

\subsection{Cardiopulmonary Exercise Testing Procedures}

Clinical exercise physiologists conducted the clinically-indicated CPET with cardiologist oversight. An institutionally designed protocol was performed on a motorized treadmill (GE Case, Milwaukee, WI, USA) with workload increasing every 2 min until volitional fatigue [22,23]. Heart rhythm and heart rate (HR) were continuously monitored via 12-lead electrocardiogram during exercise and recovery. Prior to the start of exercise and at the last $30 \mathrm{~s}$ of each stage systolic blood pressure (SBP) and diastolic blood pressure (DBP) were measured via manual sphygmomanometry. Flow and gas exchange variables were measured during exercise using indirect calorimetry (MGC Diagnostics, St. Paul, MN, USA). Peak values were obtained by averaging the last $30 \mathrm{~s}$ of the CPET data collection. Measured gas exchange variables included $\mathrm{VO}_{2 \text { peak }}$, carbon dioxide production $\left(\mathrm{VCO}_{2}\right)$, minute ventilation $\left(\mathrm{V}_{\mathrm{E}}\right)$, and respiratory exchange ratio (RER). The value of $\mathrm{V}_{\mathrm{E}} / \mathrm{VCO}_{2}$ slope was determined from rest-peak values for $\mathrm{V}_{\mathrm{E}}$ and $\mathrm{VCO}_{2}$ and \%predicted $\mathrm{VO}_{2 \text { peak }}$ [24] was calculated. Peak values were chosen for $\mathrm{V}_{\mathrm{E}} / \mathrm{VCO}_{2}$ slope as they have been shown to have superior prognostic value as opposed to the pre-ventilatory threshold slope equation [25]. Patients were monitored closely for development of significant dysrhythmia, electrocardiographic abnormalities, and/or abnormal blood pressure responses (e.g., symptomatic hypotension). Cardiac medications were not withheld prior to CPET to maximize patient safety and generalizability of the data.

\subsection{Statistical Analysis}

Data are reported as mean \pm standard deviation (SD) or frequency (percentage) where applicable. Statistical analysis was conducted using SPSS (version 22.0, Chicago, IL, USA) and JMP (JMP, Cary, NC, USA). The Student's $t$ test was used to compare pre-HTx CPET variables to post-HTx CPET variables. As previously described [26,27], univariate binary regression analysis was used to assess individual predictors for the highest post-HTx $\mathrm{VO}_{2 \text { peak }}$ (i.e., quartile 4) based on $\mathrm{VO}_{2 \text { peak }}$ data presented herein. Quartile $4=\mathrm{VO}_{2 \text { peak }}>20.1 \mathrm{~mL} / \mathrm{kg} / \mathrm{min}$, quartile $3=\mathrm{VO}_{2 \text { peak }}>17.4 \mathrm{~mL} / \mathrm{kg} / \mathrm{min}$, quartile $2=\mathrm{VO}_{2 \text { peak }}$ $>14.3 \mathrm{~mL} / \mathrm{kg} / \mathrm{min}$, and quartile $1=\mathrm{VO}_{2 \text { peak }} \leq 14.3 \mathrm{~mL} / \mathrm{kg} / \mathrm{min}$ (total range $=24.5 \mathrm{~mL} / \mathrm{kg} / \mathrm{min}$ ). A multivariate regression analysis was then performed including all significant univariate variables. Three additional adjustment analyses were conducted to account for potential factors involved in exercise capacity. Model 1 was adjusted for demographic influencers of exercise capacity (i.e., age and sex), Model 2 was adjusted for demographic and clinical influencers of exercise capacity (i.e., age, sex, BMI, history of diabetes, and hemoglobin), and Model 3 included all significant univariate predictors for multivariate analysis adjusted for age and sex. The receiver operating characteristic (ROC) curve model was assessed to establish the area under the curve (AUC) for predicting quartile 4 (i.e., the highest $\mathrm{VO}_{2 \text { peak }}$ ) and the cut-off for $\mathrm{CR}$ for maximal post- $\mathrm{HTx} \mathrm{VO}_{2 \text { peak }}$ benefits. Least squares linear 
regression analysis was performed between pre- $\mathrm{HTx} \mathrm{VO}_{2 \text { peak }}$ and post- $\mathrm{HTx} \mathrm{VO}_{2 \text { peak }}$, with reporting of the Pearson product-moment correlation coefficient $(\mathrm{r})$ as an indicator of the strength of association between before and after measurements. For all analyses, statistical significance was set at an alpha level of $p<0.05$.

\section{Results}

\subsection{Patient Population and Clinical Characteristics}

Demographic and clinical characteristics of the patients included are presented in Table 1. Of the 140 HTx patients analyzed in this study the mean age was $52 \pm 12$ years, mean BMI was $27 \pm 5 \mathrm{~kg} / \mathrm{m}^{2}$, and $n=41(29 \%)$ were women. All data shown in Table 1 was obtained from each patient within 24 months prior to procedural data. The mean number of CR sessions attended was $18 \pm 9$, with a range of 2-36 sessions.

Table 1. Recipient demographics and clinical characteristics.

\begin{tabular}{|c|c|}
\hline$n$ & 140 \\
\hline Age (years) & $52 \pm 12$ \\
\hline Sex (Female) & $41(29)$ \\
\hline Height $(\mathrm{cm})$ & $172 \pm 14$ \\
\hline Weight (kg) & $83 \pm 19$ \\
\hline $\operatorname{BSA}\left(\mathrm{m}^{2}\right)$ & $2.0 \pm 0.2$ \\
\hline $\mathrm{BMI}\left(\mathrm{kg} / \mathrm{m}^{2}\right)$ & $27.1 \pm 4.6$ \\
\hline History of Diabetes & $31(22.1)$ \\
\hline History of Smoking & $52(37.1)$ \\
\hline History of Dyslipidemia & $74(52.9)$ \\
\hline History of Hypertension & $63(45)$ \\
\hline Previous LVAD & $27(19.3)$ \\
\hline \multicolumn{2}{|l|}{ Indication for Heart Transplant } \\
\hline Restrictive Cardiomyopathy & $29(20.7)$ \\
\hline Dilated Cardiomyopathy & $53(37.9)$ \\
\hline Hypertrophic Cardiomyopathy & $8(5.6)$ \\
\hline Ischemic Cardiomyopathy & $25(17.9)$ \\
\hline Other & $25(17.9)$ \\
\hline \multicolumn{2}{|l|}{ Labs } \\
\hline Hemoglobin (g/dL) & $12.0 \pm 2.0$ \\
\hline Hematocrit $(\%)$ & $36 \pm 6$ \\
\hline White Blood Cell Count $\left(10^{9} / \mathrm{L}\right)$ & $7.5 \pm 3.0$ \\
\hline Creatinine $(\mathrm{mg} / \mathrm{dL})$ & $1.4 \pm 1.0$ \\
\hline \multicolumn{2}{|l|}{ Medications * } \\
\hline ACE Inhibitor & $52(37.1)$ \\
\hline Amiodarone & $12(8.6)$ \\
\hline Aspirin & $65(46.4)$ \\
\hline Beta Blocker & $103(73.6)$ \\
\hline Calcium Channel Blocker & $3(2.1)$ \\
\hline Diuretic & $92(65.7)$ \\
\hline Number of CR Exercise Sessions & $18 \pm 9$ \\
\hline
\end{tabular}

Note: BMI, body mass index; BSA, body surface area; CR, cardiac rehabilitation; LVAD, left ventricular assist device. All data are presented as mean \pm standard deviation or frequency (percentage). *, medication distributions are prior to cardiac transplantation procedure; $\mathrm{ACE}$, angiotensin converting enzyme.

\subsection{Exercise Testing Data Prior to and Following Transplant}

Peak exercise testing data for CPET pre-HTx versus post-HTx are shown in Table 2. All variables included show significant improvements from pre-HTx to post-HTx, with $\mathrm{V}_{\mathrm{E}} / \mathrm{VCO}_{2}$ slope decreasing while all other variables increased. Notably, relative $\mathrm{VO}_{2 \text { peak }}$ increased substantially from pre- to post-HTx $(12.9 \pm 4.4$ vs. $17.5 \pm 4.6 \mathrm{~mL} / \mathrm{kg} / \mathrm{min}, p<0.001)$. A significant positive correlation was 
present between pre-HTx $\mathrm{VO}_{2 \text { peak }}$ and post-HTx $\mathrm{VO}_{2 \text { peak }}$ (Figure 2) $(r=0.47, p<0.01)$. Additionally, this correlation between pre and post-HTx $\mathrm{VO}_{2 \text { peak }}$ was further analyzed with adjustment for the number of $C R$ exercise sessions attended and remained significant $(p<0.001)$.

Table 2. Peak exercise testing values prior to and following cardiac transplantation.

\begin{tabular}{cccc}
\hline & Pre-HTx & Post-HTx & $p$-Value \\
\hline$n$ & 140 & 140 & \\
Exercise time (min) & $5.3 \pm 1.7$ & $6.7 \pm 1.7$ & $<0.001$ \\
METS & $4.9 \pm 1.8$ & $6.4 \pm 1.8$ & $<0.001$ \\
Absolute $\mathrm{VO}_{2 \text { peak }}(\mathrm{L} / \mathrm{min})$ & $1.1 \pm 0.4$ & $1.4 \pm 0.4$ & $<0.001$ \\
$\mathrm{VO}_{2 \text { peak } \% \text { Predicted }(\%)}$ & $42 \pm 14$ & $58 \pm 17$ & $<0.001$ \\
Relative VO 2 peak $(\mathrm{mL} / \mathrm{kg} / \mathrm{min})$ & $12.9 \pm 4.4$ & $17.5 \pm 4.7$ & $<0.001$ \\
$\mathrm{~V}_{\mathrm{E}} / \mathrm{VCO}_{2}$ slope & $42 \pm 12$ & $37 \pm 6$ & $<0.001$ \\
$\mathrm{VCO}_{2}(\mathrm{~L} / \mathrm{min})$ & $1.2 \pm 0.5$ & $1.7 \pm 0.5$ & $<0.001$ \\
$\mathrm{RER}$ & $1.15 \pm 0.13$ & $1.21 \pm 0.12$ & $<0.001$ \\
$\mathrm{SBP}(\mathrm{mmHg})$ & $105 \pm 25$ & $145 \pm 30$ & $<0.001$ \\
$\mathrm{DBP}(\mathrm{mmHg})$ & $60 \pm 10$ & $67 \pm 11$ & $<0.001$ \\
$\mathrm{HR}(\mathrm{bpm})$ & $110 \pm 21$ & $125 \pm 20$ & \\
\hline
\end{tabular}

METS, metabolic equivalents; RER, respiratory exchange ratio; SBP, systolic blood pressure; DBP, diastolic blood pressure; $\mathrm{HR}$, heart rate; $\mathrm{VCO}_{2}$, production of carbon dioxide; $\mathrm{V}_{\mathrm{E}}$, minute ventilation; $\mathrm{V}_{\mathrm{E}} / \mathrm{VCO}_{2}$ slope, ventilatory efficiency; $\mathrm{VO}_{2 \text { peak, }}$ peak oxygen uptake.

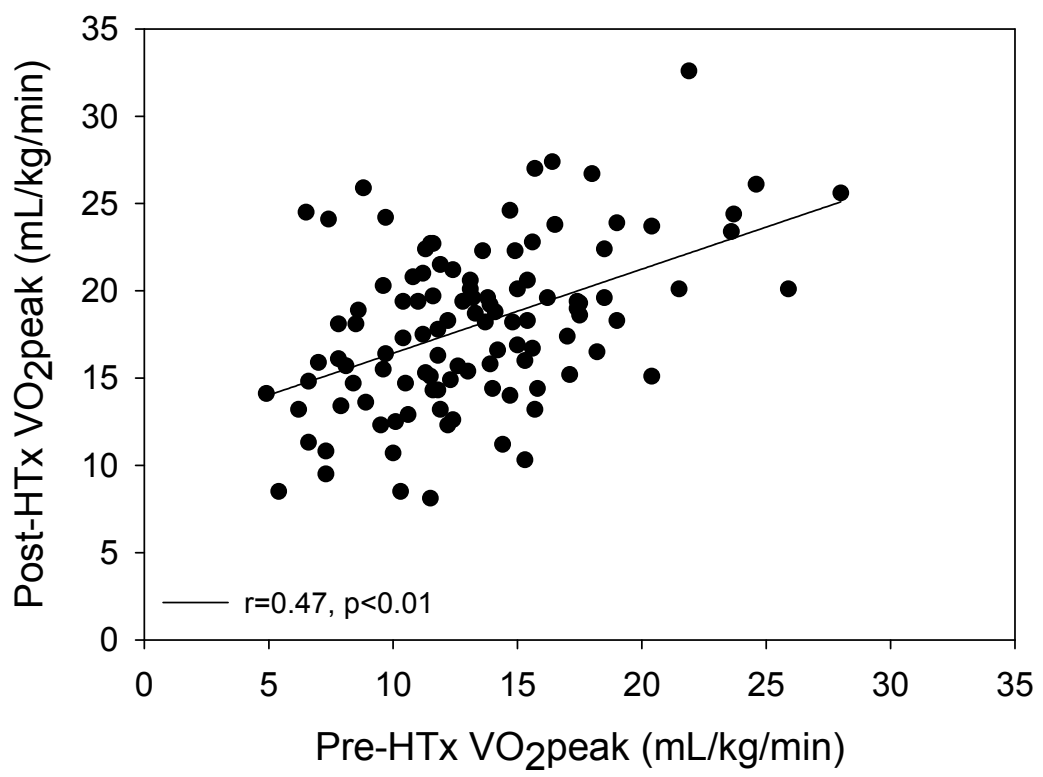

Figure 2. Relationship between measurements of relative $\mathrm{VO}_{2 \text { peak }}$ from pre-HTx to post-HTx. A significant positive correlation was present between pre-HTx $\mathrm{VO}_{2 \text { peak }}$ and post-HTx $\mathrm{VO}_{2 \text { peak }}(r=0.47$, $p<0.01)$. Post-HTx: following cardiac transplantation; Pre-HTx: prior to cardiac transplantation; $\mathrm{VO}_{2 \text { peak: }}$ peak oxygen uptake.

\subsection{Predictors of $V O_{2 p e a k}$}

Univariate regression analysis indicated that BMI, history of diabetes, history of dyslipidemia, hemoglobin, white blood cell count, $\mathrm{CR}$ exercise sessions, and pre- $\mathrm{HTx} \mathrm{VO}_{2 \text { peak }}$ were significant predictors of higher $\mathrm{VO}_{2 \text { peak }}$ post-HTx (Table 3). The significance of pre-HTx $\mathrm{VO}_{2 \text { peak }}$ and CR exercise sessions on post-HTx $\mathrm{VO}_{2 \text { peak }}$ remained after adjustment for demographic influencers of exercise capacity (age and sex) as shown in Model 1, and adjustment for demographic and clinical influencers of exercise capacity (age, sex, BMI, history of diabetes, hemoglobin, peak HR, and HR recovery (HRR)) as shown in Model 2 (Table 4). 
Table 3. Univariate regression analysis for predictors of $\mathrm{VO}_{2 \text { peak }}$.

\begin{tabular}{|c|c|c|c|}
\hline \multirow{2}{*}{ Variable } & \multicolumn{3}{|c|}{ Univariate Analysis } \\
\hline & OR & $95 \% \mathrm{CI}$ & $p$-Value \\
\hline Age (years) & 0.978 & 0.949-1.009 & 0.170 \\
\hline Sex (female) & 0.457 & 0.173-1.209 & 0.115 \\
\hline $\mathrm{BMI}\left(\mathrm{kg} / \mathrm{m}^{2}\right)$ & 0.896 & $0.815-0.985$ & 0.022 \\
\hline History of Diabetes & 0.174 & $0.039-0.772$ & 0.021 \\
\hline History of Smoking & 0.805 & $0.354-1.831$ & 0.605 \\
\hline History of Hypertension & 0.741 & $0.335-1.641$ & 0.460 \\
\hline History of Dyslipidemia & 0.415 & $0.185-0.929$ & 0.032 \\
\hline History of LVAD & 1.171 & $0.446-3.076$ & 0.748 \\
\hline \multicolumn{4}{|l|}{ Indication for HTx } \\
\hline Restrictive Cardiomyopathy & 0.812 & $0.299-2.201$ & 0.682 \\
\hline Dilated Cardiomyopathy & 0.920 & $0.409-2.066$ & 0.840 \\
\hline Hypertrophic Cardiomyopathy & 2.040 & 0.461-9.035 & 0.348 \\
\hline Ischemic Cardiomyopathy & 0.565 & $0.179-1.782$ & 0.330 \\
\hline Other & 1.694 & $0.655-4.380$ & 0.277 \\
\hline \multicolumn{4}{|l|}{ Labs } \\
\hline Hemoglobin (g/dL) & 1.294 & $1.041-1.608$ & 0.020 \\
\hline Hematocrit $(\%)$ & 1.063 & $0.985-1.146$ & 0.115 \\
\hline White Blood Cell Count $\left(10^{9} / \mathrm{L}\right)$ & 0.806 & $0.662-0.982$ & 0.033 \\
\hline Creatinine $(\mathrm{mg} / \mathrm{dL})$ & 0.402 & $0.155-1.039$ & 0.060 \\
\hline \multicolumn{4}{|l|}{ Pre-HTx CPET Data } \\
\hline Peak SBP (mmHg) & 0.998 & $0.971-1.005$ & 0.158 \\
\hline Heart Rate Recovery (bpm) & 1.021 & $0.987-1.056$ & 0.225 \\
\hline Relative $\mathrm{VO}_{2 \text { peak }}(\mathrm{mL} / \mathrm{kg} / \mathrm{min})$ & 1.174 & $1.070-1.289$ & 0.001 \\
\hline CR Exercise Sessions & 1.095 & $1.041-1.152$ & $<0.001$ \\
\hline
\end{tabular}

OR, odds ratio; CI, confidence interval; BMI, body mass index; CR, cardiac rehabilitation; HTx, cardiac transplantation; $\mathrm{LVAD}$, left ventricular assist device; $\mathrm{SBP}$, systolic blood pressure, $\mathrm{VO}_{2 \text { peak}}$, peak oxygen uptake.

Table 4. Adjusted and multivariate regression analysis for predictors of Post- $\mathrm{HTx} \mathrm{VO}_{2 \text { peak }}$.

\begin{tabular}{|c|c|c|c|c|c|c|c|c|c|}
\hline \multirow{2}{*}{ Variable } & \multicolumn{3}{|c|}{ Model 1} & \multicolumn{3}{|c|}{ Model 2} & \multicolumn{3}{|c|}{ Model 3} \\
\hline & OR & $95 \%$ CI & $p$-Value & OR & $95 \%$ CI & $p$-Value & OR & $95 \%$ CI & $p$-Value \\
\hline Age (years) & 0.968 & $0.932-1.006$ & 0.094 & 0.970 & $0.933-1.009$ & 0.130 & 0.962 & $0.922-1.004$ & 0.077 \\
\hline BMI $\left(\mathrm{kg} / \mathrm{m}^{2}\right)$ & & & & 0.889 & $0.791-0.999$ & 0.049 & 0.097 & $0.811-1.018$ & 0.097 \\
\hline History of Diabetes & & & & 3.050 & $0.602-15.450$ & 0.178 & 2.760 & $0.635-11.995$ & 0.176 \\
\hline $\begin{array}{c}\text { History of Dyslipidemia } \\
\text { Labs }\end{array}$ & & & & & & & 0.880 & $0.315-2.465$ & 0.807 \\
\hline $\begin{array}{l}\text { White Blood Cell Count }\left(10^{9} / \mathrm{L}\right) \\
\text { Pre-HTx CPET Data }\end{array}$ & & & & & & & 0.796 & $0.620-1.021$ & 0.072 \\
\hline Relative $\mathrm{VO}_{2 \text { peak }}(\mathrm{mL} / \mathrm{kg} / \mathrm{min})$ & 1.145 & $1.037-1.264$ & 0.007 & 1.110 & $1.002-1.231$ & 0.047 & 1.206 & $1.068-1.361$ & 0.002 \\
\hline Peak HR (bpm) & & & & 0.979 & $0.951-1.007$ & 0.147 & & & \\
\hline HRR (bpm) & & & & 1.008 & $0.959-1.059$ & 0.764 & & & \\
\hline CR Exercise Sessions & 1.102 & $1.037-1.264$ & $<0.001$ & 1.095 & $1.037-1.157$ & 0.001 & 1.103 & $1.042-1.167$ & 0.001 \\
\hline
\end{tabular}

$\mathrm{OR}$, odds ratio; $\mathrm{CI}$, confidence interval; $\mathrm{BMI}$, body mass index; $\mathrm{CPET}$, cardiopulmonary exercise testing; $\mathrm{CR}$, cardiac rehabilitation; HR, heart rate; HRR, heart rate recovery; LVAD, left ventricular assist device; SBP, systolic blood pressure; $\mathrm{VO}_{2 \text { peak, }}$ peak oxygen uptake. Model 1: Adjustment for age and sex. Model 2: Adjustment for age, sex, and influencers of exercise capacity (body mass index, history of diabetes, hemoglobin, peak HR, and HRR). Model 3: Significant univariate predictors in multivariate analysis with adjustment for age and sex.

All significant univariate predictors were included into the multivariate regression analysis with adjustment for age and sex. This analysis (as shown in Model 3) indicated that CR exercise sessions and pre-HTx $\mathrm{VO}_{2 \text { peak }}$ were the independent predictors of higher post- $\mathrm{HTx} \mathrm{VO}_{2 \text { peak }}$ (Table 4). When $\mathrm{CR}$ exercise session attendance was divided into two groups by the median attendance of 18 sessions, those who attended $\geq 18$ sessions had significantly higher post-HTx $\mathrm{VO}_{2 \text { peak }}$ compared to those with $<18$ sessions attended ( $\geq 18$ sessions: $18.8 \pm 4.8$ vs. $<18$ sessions: $16.4 \pm 4.3, p<0.01$ ) (Figure 3 ). The 
value of 18 sessions was also determined to be an appropriate cutoff for $\mathrm{CR}$ attendance necessary to maximize benefits in post-HTx $\mathrm{VO}_{2 \text { peak }}$ (AUC: 0.692 , specificity: 0.549 , sensitivity: $0.684, p<0.001$ ).

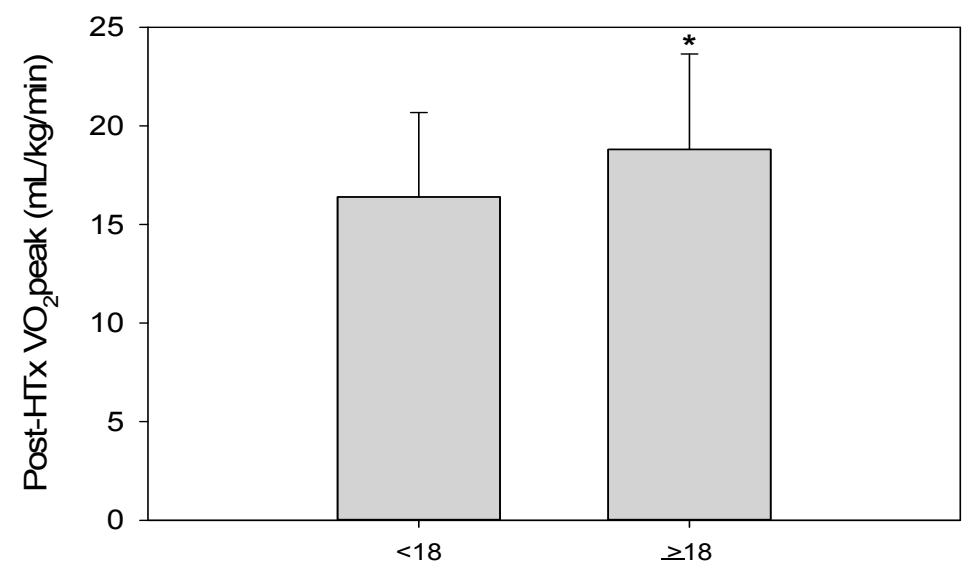

Number of CR Exercise Sessions

Figure 3. Post-HTx $\mathrm{VO}_{2 \text { peak }}$ based on median $\mathrm{CR}$ exercise session attendance. Those HTx patients who attended $\geq 18 \mathrm{CR}$ exercise sessions had significantly higher post- $\mathrm{HTx} \mathrm{VO}_{2 \text { peak }}$ compared to those with $<18$ CR exercise sessions attended ( $\geq 18$ sessions: $18.8 \pm 4.8$ vs. $<18$ sessions: $16.4 \pm 4.3, p<0.01$ ) *, significantly higher than $<18$ CR sessions. CR: cardiac rehabilitation; Post-HTx: following cardiac transplantation; $\mathrm{VO}_{2 \text { peak }}$ : peak oxygen uptake.

\section{Discussion}

The purpose of this study was to determine whether pre-HTx clinical characteristics and/or postoperative participation in $\mathrm{CR}$ provide utility in predicting $\mathrm{VO}_{2 \text { peak }}$ following HTx. Pre-HTx $\mathrm{VO}_{2 \text { peak }}$ and the number of $\mathrm{CR}$ exercise sessions attended were the only variables predictive of greater $\mathrm{VO}_{2 \text { peak }}$ following HTx. These metrics independently predicted higher post-HTx $\mathrm{VO}_{2 \text { peak }}$ even after adjusting for other factors of exercise capacity, surpassing other significant univariate factors. Our data provide new evidence of the critical benefits of CR in improving functional capacity following HTx.

Previous work has evaluated potential predictors of $\mathrm{VO}_{2 \text { peak }}$ in various populations [10-14,17,18,28,29]. In healthy subjects the general characteristics of younger age, male sex, and training state have been shown to be associated with improved exercise capacity [17]. For those with cardiovascular disease (CVD), several studies measuring exercise capacity directly by $\mathrm{VO}_{2 \text { peak }}$ or indirectly using predicted METS have shown overall that age and baseline fitness are the strongest predictors of $\mathrm{VO}_{2 \text { peak }}[10,28,29]$. The predictive quality of age also remains in the HTx population $[11,13,14]$. One of the first studies to evaluate predictors of $\mathrm{VO}_{2 \text { peak }}$ specifically for HTx patients found that chronotropic reserve, donor age, recipient age, and time from HTx were the most significant predictors of $\mathrm{VO}_{2 \text { peak }}$ post-HTx [11]. This study, however, collected CPET data in the broad range of 1-100 months following HTx, which limits the specificity of temporal cardiopulmonary adaptation post-HTx. Although not significant in multivariate analysis, clinical history of diabetes and dyslipidemia were significant univariate predictors in this study, emphasizing the importance of multimorbidity management [30-33]. More recent studies in HTx patients have shown that the demographic components of sex, BMI, and age are prominent predictors of $\mathrm{VO}_{2 \text { peak }}[13,14,18]$. Table 5 provides information on four specific studies particularly relevant to the findings of the current study examining predictors of $\mathrm{VO}_{2 \text { peak }}$ in HTx patients. 
Table 5. Predictors of $\mathrm{VO}_{2 \text { peak }}$ in heart transplant patients.

\begin{tabular}{|c|c|c|c|c|c|}
\hline Study Group & $n$ & Age (yrs) & Predictors of $\mathrm{VO}_{2 \text { peak }}$ & $\begin{array}{l}\text { Time from } \\
\text { Transplant }\end{array}$ & $\begin{array}{c}\text { Post-Transplant } \\
\mathrm{VO}_{2 \text { peak }}(\mathrm{mL} / \mathrm{kg} / \mathrm{min})\end{array}$ \\
\hline Douard et al. 1997 [11] & 85 & $52 \pm 12$ & $\begin{array}{l}\text { Chronotropic reserve, time from } \\
\text { transplantation, age of donor, } \\
\text { age of patient }\end{array}$ & $1-100$ months & $21.1 \pm 6.0$ \\
\hline Leung et al. 2003 [13] & 95 & $48 \pm 14$ & $\begin{array}{l}\text { Age, sex, height, and weight } \\
\text { (alternatively, body mass index) }\end{array}$ & 12 months & $19.9 \pm 4.8$ \\
\hline Nytrøen et al. 2012 [18] & 51 & $52 \pm 16$ & $\begin{array}{c}\text { Muscular exercise capacity and } \\
\text { body fat }\end{array}$ & $1-8$ years & $\begin{array}{l}\text { Group 1: } 23.1 \pm 3.7 \\
\text { Group 2: } 32.6 \pm 4.4\end{array}$ \\
\hline Carvalho et al. 2015 [14] & 60 & $48 \pm 15$ & $\begin{array}{l}\text { Age, sex, body mass index, } \\
\text { heart rate reserve, and left } \\
\text { atrium diameter }\end{array}$ & $64 \pm 54$ months & unspecified \\
\hline
\end{tabular}

Note: $\mathrm{VO}_{2 \text { peak, }}$ peak oxygen uptake; yrs, years. All data are presented as mean \pm standard deviation unless otherwise specified.

Although the findings of these studies concur with our study regarding the predictive quality of BMI, CR exercise session attendance and baseline fitness as assessed by pre- $\mathrm{HTx} \mathrm{VO}_{2 \text { peak }}$ were the only independent predictors of post- $\mathrm{HTx} \mathrm{VO}_{2 \text { peak }}$. Baseline fitness levels have previously been shown to predict $\mathrm{VO}_{2 \text { peak }}$ in CVD patients [28,29], yet this study is the first to show this relationship in $\mathrm{HTx}$ patients. A significant correlation was present between pre-HTx $\mathrm{VO}_{2 \text { peak }}$ and post-HTx $\mathrm{VO}_{2 \text { peak }}$ in our study, as those with the highest pre-HTx $\mathrm{VO}_{2 \text { peak }}$ were more likely to have higher $\mathrm{VO}_{2 \text { peak }}$ measurements following HTx. These results highlight the importance of maintaining or reaching a higher functional capacity leading up to $\mathrm{HTx}$, as baseline values predict postoperative $\mathrm{VO}_{2 \text { peak }}$ levels.

The predictive impact of $\mathrm{CR}$ involvement following $\mathrm{HTx}$ on achieving higher $\mathrm{VO}_{2 \text { peak }}$ values was a unique component to this study. Our findings clearly demonstrate the importance of postoperative CR participation in improving functional capacity and implications of survival following HTx. Specifically following HTx, the benefits of CR involvement are widespread for this clinically unique population; including counteracting marked deconditioning and skeletal muscle weakness associated with end-stage $\mathrm{HF}$, corticosteroid treatment, and surgical recovery [18,34-36]. Although the predictive quality of $\mathrm{CR}$ session attendance has not been previously reported, the increase in $\mathrm{VO}_{2 \text { peak }}$ following $\mathrm{CR}$ in HTx patients is well-documented $[15,19,20,37,38]$. The importance of CR involvement on $\mathrm{VO}_{2 \text { peak }}$ following HTx is critical, as it elicits significantly greater increases in $\mathrm{VO}_{2 \text { peak }}$ compared to at-home therapy [37]. One such study reported an increase of $3.6 \mathrm{~mL} / \mathrm{kg} / \mathrm{min}$ in $\mathrm{VO}_{2 \text { peak }}$ following a 12-week CR program after HTx [19]. Additionally, a recent review evaluating CR exercise in HTx patients that encompassed 10 randomized controlled trials with a total of 300 patients found that exercise capacity was, on average, $2.49 \mathrm{~mL} / \mathrm{kg} / \mathrm{min}$ higher for those who exercised [15]. Our study showed a mean increase of $4.6 \mathrm{~mL} / \mathrm{kg} / \mathrm{min}$ (equivalent to over $1.5 \mathrm{METS}$ ) from pre- to post-HTx, which has substantial meaning with regard to improved quality of life and survival. Further, those who attended $>18$ sessions demonstrated a post-HTx $\mathrm{VO}_{2 \text { peak }}$ of $2.4 \mathrm{~mL} / \mathrm{kg} / \mathrm{min}$ higher than those who attended $<18$ sessions (i.e., $15 \%$ greater). Studies in $\mathrm{HF}$ have found that an increased $\mathrm{VO}_{2 \text { peak }}$ is associated with better outcomes (i.e., primary endpoints of all-cause hospitalizations and/or mortality) $[6,7,39,40]$. One such study found a $5 \%$ lower risk of all-cause mortality or hospitalization for every $6 \%$ increase in $\mathrm{VO}_{2 \text { peak, }}$, thereby highlighting the importance of even seemingly small improvements in $\mathrm{VO}_{2 \text { peak }}$ on long-term clinical outcomes [7]. It should be noted, however, that despite significant functional improvements observed following $\mathrm{HTx}, \mathrm{VO}_{2 \text { peak }}$ values still remain abnormal in HTx patients compared to age-matched control subjects [34,41,42]. Further understanding of the demographic, clinical, and rehabilitative components that predict post-HTx $\mathrm{VO}_{2 \text { peak }}$ values offers greater insight into the complex cardiopulmonary and peripheral adaptations occurring following HTx.

It is important to recognize the retrospective observational nature of the present study design. Additional research in this area is encouraged to confirm these results in a prospective fashion. The distribution of post-HTx medications could potentially influence CPET measurements, therefore this should be taken into account as a limitation to the application of these results. Further, data 
pertaining to donor information (e.g., donor age, donor sex) and surgical procedural notes (e.g., cold ischemic time) were unavailable for this study and may be important additional metrics to include in follow-up studies.

\section{Conclusions}

In summary, HTx patients demonstrated substantial improvements in $\mathrm{VO}_{2 \text { peak }}$ following HTx. The only factors that provided significant predictive value of higher post- $\mathrm{HTx} \mathrm{VO}_{2 \text { peak }}$ values were $\mathrm{CR}$ exercise session attendance and pre-HTx $\mathrm{VO}_{2 \text { peak, }}$, even after adjustment for other univariate predictors of post-HTx exercise capacity. These data demonstrate the influential role of sustaining and/or improving cardiorespiratory fitness leading up to and following HTx, specifically in the CR setting.

Author Contributions: Conceptualization, K.E.U., J.R.W.S., J.R.M.-I., E.H.V.I., T.P.O.; Methodology, K.E.U., J.R.W.S., J.R.M.-I., E.H.V.I., R.W.S., T.P.O.; Software, K.E.U., J.R.W.S., J.R.M.-I.; Validation, K.E.U., J.R.W.S., J.R.M.-I.; Formal Analysis, K.E.U., J.R.W.S., J.R.M.-I., T.P.O.; Investigation, K.E.U., J.R.W.S., J.R.M.-I., E.H.V.I., R.W.S., T.P.O.; Resources, K.E.U., J.R.W.S., J.R.M.-I., E.H.V.I., R.W.S., T.P.O.; Data Curation, K.E.U., J.R.W.S., J.R.M.-I., T.P.O.; Writing-Original Draft Preparation, K.E.U., J.R.W.S.; Writing—Review and Editing, J.R.W.S., J.R.M.-I., R.W., T.P.O.; Visualization, K.E.U., J.R.W.S., J.R.M.-I., R.W., T.P.O.; Supervision, J.R.W.S., T.P.O.; Project Administration, J.R.W.S., T.P.O.; Funding Acquisition, J.R.W.S., T.P.O.

Funding: This research was funded by the National Institutes of Health [HL-126638 to TPO] and American Heart Association [18POST3990251 to JRS].

Conflicts of Interest: The authors declare no conflict of interest.

\section{References}

1. Mancini, D.M.; Eisen, H.; Kussmaul, W.; Mull, R.; Edmunds, L.H., Jr.; Wilson, J.R. Value of peak exercise oxygen consumption for optimal timing of cardiac transplantation in ambulatory patients with heart failure. Circulation 1991, 83, 778-786. [CrossRef] [PubMed]

2. Elmariah, S.; Goldberg, L.R.; Allen, M.T.; Kao, A. Effects of gender on peak oxygen consumption and the timing of cardiac transplantation. J. Am. Coll. Cardiol. 2006, 47, 2237-2242. [CrossRef] [PubMed]

3. Ponikowski, P.; Voors, A.A.; Anker, S.D.; Bueno, H.; Cleland, J.G.; Coats, A.J.; Falk, V.; Gonzalez-Juanatey, J.R.; Harjola, V.P.; Jankowska, E.A.; et al. 2016 ESC Guidelines for the diagnosis and treatment of acute and chronic heart failure. Kardiol. Pol. 2016, 74, 1037-1147. [CrossRef] [PubMed]

4. Mehra, M.R.; Canter, C.E.; Hannan, M.M.; Semigran, M.J.; Uber, P.A.; Baran, D.A.; Danziger-Isakov, L.; Kirklin, J.K.; Kirk, R.; Kushwaha, S.S.; et al. The 2016 International Society for Heart Lung Transplantation listing criteria for heart transplantation: A 10-year update. J. Heart Lung Transplant. 2016, 35, 1-23. [CrossRef] [PubMed]

5. Peterson, L.R.; Schechtman, K.B.; Ewald, G.A.; Geltman, E.M.; Meyer, T.; Krekeler, P.; Rogers, J.G. The effect of beta-adrenergic blockers on the prognostic value of peak exercise oxygen uptake in patients with heart failure. J. Heart Lung Transplant. 2003, 22, 70-77. [CrossRef]

6. Keteyian, S.J.; Patel, M.; Kraus, W.E.; Brawner, C.A.; McConnell, T.R.; Pina, I.L.; Leifer, E.S.; Fleg, J.L.; Blackburn, G.; Fonarow, G.C.; et al. Variables measured during cardiopulmonary exercise testing as predictors of mortality in chronic systolic heart failure. J. Am. Coll. Cardiol. 2016, 67, 780-789. [CrossRef] [PubMed]

7. Swank, A.M.; Horton, J.; Fleg, J.L.; Fonarow, G.C.; Keteyian, S.; Goldberg, L.; Wolfel, G.; Handberg, E.M.; Bensimhon, D.; Illiou, M.C.; et al. Modest increase in peak $\mathrm{VO}_{2}$ is related to better clinical outcomes in chronic heart failure patients: Results from heart failure and a controlled trial to investigate outcomes of exercise training. Circ. Heart Fail. 2012, 5, 579-585. [CrossRef] [PubMed]

8. Kavanagh, T.; Mertens, D.J.; Shephard, R.J.; Beyene, J.; Kennedy, J.; Campbell, R.; Sawyer, P.; Yacoub, M. Long-term cardiorespiratory results of exercise training following cardiac transplantation. Am. J. Cardiol. 2003, 91, 190-194. [CrossRef]

9. Yardley, M.; Havik, O.E.; Grov, I.; Relbo, A.; Gullestad, L.; Nytroen, K. Peak oxygen uptake and self-reported physical health are strong predictors of long-term survival after heart transplantation. Clin. Transplant. 2016, 30, 161-169. [CrossRef] 
10. Branco, C.F.; Viamonte, S.; Matos, C.; Magalhaes, S.; Cunha, I.; Barreira, A.; Fernandes, P.; Torres, S. Predictors of changes in functional capacity on a cardiac rehabilitation program. Rev. Port. Cardiol. 2016, 35, 215-224. [CrossRef]

11. Douard, H.; Parrens, E.; Billes, M.A.; Labbe, L.; Baudet, E.; Broustet, J.P. Predictive factors of maximal aerobic capacity after cardiac transplantation. Eur. Heart J. 1997, 18, 1823-1828. [CrossRef] [PubMed]

12. Hammond, H.K.; Kelly, T.L.; Froelicher, V.F.; Pewen, W. Use of clinical data in predicting improvement in exercise capacity after cardiac rehabilitation. J. Am. Coll. Cardiol. 1985, 6, 19-26. [CrossRef]

13. Leung, T.C.; Ballman, K.V.; Allison, T.G.; Wagner, J.A.; Olson, L.J.; Frantz, R.P.; Edwards, B.S.; Dearani, J.A.; Daly, R.C.; McGregor, C.G.; et al. Clinical predictors of exercise capacity 1 year after cardiac transplantation. J. Heart Lung Transplant. 2003, 22, 16-27. [CrossRef]

14. Oliveira Carvalho, V.; Guimaraes, G.V.; Vieira, M.L.; Catai, A.M.; Oliveira-Carvalho, V.; Ayub-Ferreira, S.M.; Bocchi, E.A. Determinants of peak $\mathrm{VO}_{2}$ in heart transplant recipients. Rev. Bras. Cir. Cardiovasc. 2015, 30, 9-15. [CrossRef]

15. Anderson, L.; Nguyen, T.T.; Dall, C.H.; Burgess, L.; Bridges, C.; Taylor, R.S. Exercise-based cardiac rehabilitation in heart transplant recipients. Cochrane Database Syst. Rev. 2017, 4, CD012264. [CrossRef] [PubMed]

16. Ogawa, T.; Spina, R.J.; Martin, W.H., 3rd; Kohrt, W.M.; Schechtman, K.B.; Holloszy, J.O.; Ehsani, A.A. Effects of aging, sex, and physical training on cardiovascular responses to exercise. Circulation 1992, 86, 494-503. [CrossRef] [PubMed]

17. Woo, J.S.; Derleth, C.; Stratton, J.R.; Levy, W.C. The influence of age, gender, and training on exercise efficiency. J. Am. Coll. Cardiol. 2006, 47, 1049-1057. [CrossRef]

18. Nytroen, K.; Rustad, L.A.; Gude, E.; Hallen, J.; Fiane, A.E.; Rolid, K.; Holm, I.; Aakhus, S.; Gullestad, L. Muscular exercise capacity and body fat predict $\mathrm{VO}(2$ peak) in heart transplant recipients. Eur. J. Prev. Cardiol. 2014, 21, 21-29. [CrossRef]

19. Hsu, C.J.; Chen, S.Y.; Su, S.; Yang, M.C.; Lan, C.; Chou, N.K.; Hsu, R.B.; Lai, J.S.; Wang, S.S. The effect of early cardiac rehabilitation on health-related quality of life among heart transplant recipients and patients with coronary artery bypass graft surgery. Transplant. Proc. 2011, 43, 2714-2717. [CrossRef]

20. Rosenbaum, A.N.; Kremers, W.K.; Schirger, J.A.; Thomas, R.J.; Squires, R.W.; Allison, T.G.; Daly, R.C.; Kushwaha, S.S.; Edwards, B.S. Association between early cardiac rehabilitation and long-term survival in cardiac transplant recipients. Mayo Clin. Proc. 2016, 91, 149-156. [CrossRef]

21. Yawn, B.P.; Yawn, R.A.; Geier, G.R.; Xia, Z.; Jacobsen, S.J. The impact of requiring patient authorization for use of data in medical records research. J. Fam. Pract. 1998, 47, 361-365. [PubMed]

22. Squires, R.W.; Allison, T.G.; Johnson, B.D.; Gau, G.T. Non-physician supervision of cardiopulmonary exercise testing in chronic heart failure: Safety and results of a preliminary investigation. J. Cardiopulm. Rehabil. 1999, 19, 249-253. [CrossRef] [PubMed]

23. Larsen, C.M.; Ball, C.A.; Hebl, V.B.; Ong, K.C.; Siontis, K.C.; Olson, T.P.; Ackerman, M.J.; Ommen, S.R.; Allison, T.G.; Geske, J.B. Effect of body mass index on exercise capacity in patients with hypertrophic cardiomyopathy. Am. J. Cardiol. 2017. [CrossRef] [PubMed]

24. Myers, J.; Kaminsky, L.A.; Lima, R.; Christle, J.W.; Ashley, E.; Arena, R. A reference equation for normal standards for $\mathrm{VO}_{2}$ Max: Analysis from the Fitness Registry and the Importance of Exercise National Database (FRIEND Registry). Prog. Cardiovasc. Dis. 2017, 60, 21-29. [CrossRef] [PubMed]

25. Arena, R.; Humphrey, R.; Peberdy, M.A. Prognostic ability of $\mathrm{V}_{\mathrm{E}} / \mathrm{VCO}_{2}$ slope calculations using different exercise test time intervals in subjects with heart failure. Eur. J. Cardiovasc. Prev. Rehabil. 2003, 10, 463-468. [CrossRef] [PubMed]

26. Francis, D.P.; Shamim, W.; Davies, L.C.; Piepoli, M.F.; Ponikowski, P.; Anker, S.D.; Coats, A.J. Cardiopulmonary exercise testing for prognosis in chronic heart failure: Continuous and independent prognostic value from $\mathrm{V}_{\mathrm{E}} / \mathrm{VCO}_{2}$ slope and peak $\mathrm{VO}_{2}$. Eur. Heart J. 2000, 21, 154-161. [CrossRef] [PubMed]

27. Smith, J.R.; Medina-Inojosa, J.R.; Layrisse, V.; Ommen, S.R.; Olson, T.P. Predictors of exercise capacity in patients with hypertrophic obstructive cardiomyopathy. J. Clin. Med. 2018, 7. [CrossRef]

28. Pierson, L.M.; Miller, L.E.; Herbert, W.G. Predicting exercise training outcome from cardiac rehabilitation. J. Cardiopulm. Rehabil. 2004, 24, 113-118. [CrossRef] 
29. McKee, G.; Kerins, M.; Fitzgerald, G.; Spain, M.; Morrison, K. Factors that influence obesity, functional capacity, anxiety and depression outcomes following a Phase III cardiac rehabilitation programme. J. Clin. Nurs. 2013, 22, 2758-2767. [CrossRef]

30. Fang, Z.Y.; Sharman, J.; Prins, J.B.; Marwick, T.H. Determinants of exercise capacity in patients with type 2 diabetes. Diabetes Care 2005, 28, 1643-1648. [CrossRef]

31. Higgins, J.; Pflugfelder, P.W.; Kostuk, W.J. Increased morbidity in diabetic cardiac transplant recipients. Can. J. Cardiol. 2009, 25, e125-e129. [CrossRef]

32. Horwich, T.B.; Hamilton, M.A.; Maclellan, W.R.; Fonarow, G.C. Low serum total cholesterol is associated with marked increase in mortality in advanced heart failure. J. Card Fail. 2002, 8, 216-224. [CrossRef] [PubMed]

33. Rauchhaus, M.; Clark, A.L.; Doehner, W.; Davos, C.; Bolger, A.; Sharma, R.; Coats, A.J.; Anker, S.D. The relationship between cholesterol and survival in patients with chronic heart failure. J. Am. Coll. Cardiol. 2003, 42, 1933-1940. [CrossRef] [PubMed]

34. Tucker, W.J.; Beaudry, R.I.; Samuel, T.J.; Nelson, M.D.; Halle, M.; Baggish, A.L.; Haykowsky, M.J. Performance limitations in heart transplant recipients. Exerc. Sport Sci. Rev. 2018, 46, 144-151. [CrossRef]

35. Georgiadou, P.; Adamopoulos, S. Skeletal muscle abnormalities in chronic heart failure. Curr. Heart Fail. Rep. 2012, 9, 128-132. [CrossRef] [PubMed]

36. Lampert, E.; Mettauer, B.; Hoppeler, H.; Charloux, A.; Charpentier, A.; Lonsdorfer, J. Structure of skeletal muscle in heart transplant recipients. J. Am. Coll. Cardiol. 1996, 28, 980-984. [CrossRef]

37. Kobashigawa, J.A.; Leaf, D.A.; Lee, N.; Gleeson, M.P.; Liu, H.; Hamilton, M.A.; Moriguchi, J.D.; Kawata, N.; Einhorn, K.; Herlihy, E.; et al. A controlled trial of exercise rehabilitation after heart transplantation. N. Engl. J. Med. 1999, 340, 272-277. [CrossRef]

38. Daida, H.; Squires, R.W.; Allison, T.G.; Johnson, B.D.; Gau, G.T. Sequential assessment of exercise tolerance in heart transplantation compared with coronary artery bypass surgery after phase II cardiac rehabilitation. Am. J. Cardiol. 1996, 77, 696-700. [CrossRef]

39. Pina, I.L.; Bittner, V.; Clare, R.M.; Swank, A.; Kao, A.; Safford, R.; Nigam, A.; Barnard, D.; Walsh, M.N.; Ellis, S.J.; et al. Effects of exercise training on outcomes in women with heart failure: Analysis of HF-ACTION (Heart Failure-A Controlled Trial Investigating Outcomes of Exercise TraiNing) by sex. JACC Heart Fail. 2014, 2, 180-186. [CrossRef]

40. Sarullo, F.M.; Fazio, G.; Brusca, I.; Fasullo, S.; Paterna, S.; Licata, P.; Novo, G.; Novo, S.; Di Pasquale, P. Cardiopulmonary exercise testing in patients with chronic heart failure: Prognostic comparison from peak $\mathrm{VO}_{2}$ and $\mathrm{V}_{\mathrm{E}} / \mathrm{VCO}_{2}$ Slope. Open Cardiovasc. Med. J. 2010, 4, 127-134. [CrossRef]

41. Givertz, M.M.; Hartley, L.H.; Colucci, W.S. Long-term sequential changes in exercise capacity and chronotropic responsiveness after cardiac transplantation. Circulation 1997, 96, 232-237. [CrossRef] [PubMed]

42. Kao, A.C.; Van Trigt, P., 3rd; Shaeffer-McCall, G.S.; Shaw, J.P.; Kuzil, B.B.; Page, R.D.; Higginbotham, M.B. Central and peripheral limitations to upright exercise in untrained cardiac transplant recipients. Circulation 1994, 89, 2605-2615. [CrossRef] [PubMed]

(C) 2019 by the authors. Licensee MDPI, Basel, Switzerland. This article is an open access article distributed under the terms and conditions of the Creative Commons Attribution (CC BY) license (http://creativecommons.org/licenses/by/4.0/). 